\title{
The Machining of BRAKe Discs
}

\author{
WOLNY, R. \& RYGALLO, A.
}

Abstract: In the paper constructional solutions of brake discs were presented. Technological process of their carrying out in the large-lot production was discussed. The semi-automatic seat to mechanical treatment of brake discs was characterized. The main goal of this paper was the modification and optimization of technological process of brake discs treatment. Machine cutting parameters were optimized and changes in NC programs for lathes and borers were implemented. An attempt of applying ceramic cutting plates with another optimization of machining parameters was made. Applied changes improved the efficiency without worsening the precision of work.

Key words: brake disc, technological process, CNC machine, modification, optimization
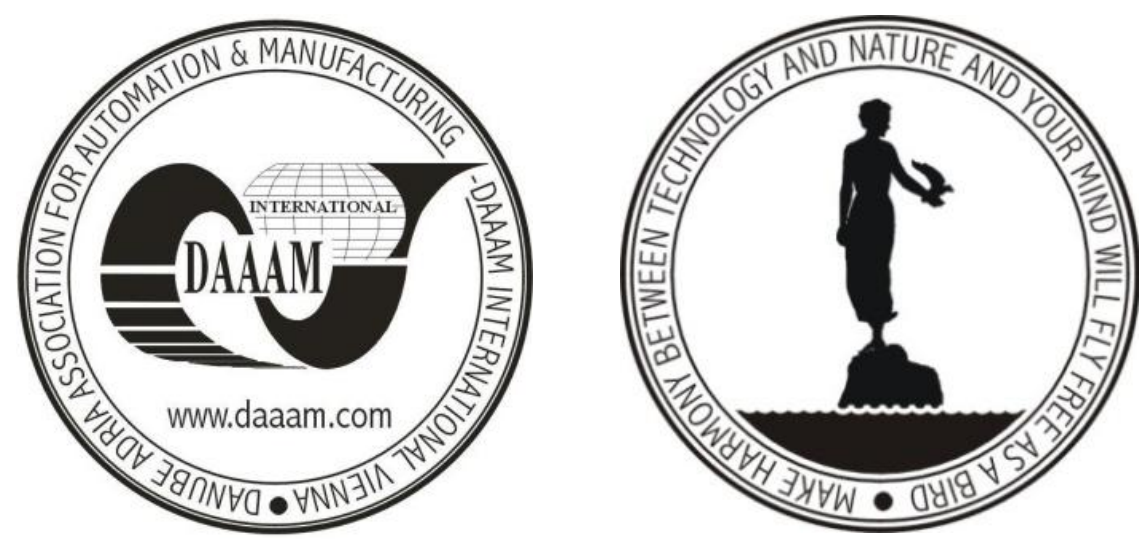

Authors' data: Dr. Wolny, R[yszard]; Dr. Rygallo, A[ndrzej], Czestochowa University of Technology, Dabrowskiego 69, 42-200 Czestochowa, Poland, rwolny@itm.pcz.pl, andryg@ pro.onet.pl

This Publication has to be referred as: Wolny, R[yszard] \& Rygallo, A[ndrzej] (2010). The Machining of Brake Discs, Chapter 18 in DAAAM International Scientific Book 2010, pp. 169-176, B. Katalinic (Ed.), Published by DAAAM International, ISBN 978-3-901509-74-2, ISSN 1726-9687, Vienna, Austria

DOI: $10.2507 /$ daaam.scibook.2010.18 


\section{Introduction}

In the period from 1890 to 1895 Karl Benz, F. W. Lanchester, Albert de Dion and Georges Bouton constructed the first cars and put them on the market. In 1902, Lanchester submitted a patent application for the brake disc. At the same time, a considerable progress in the brake technology was made by Herbert Frood (Ferodo), who developed and patented the first modern abrasive materials. In 1922, Malcolm Loughead (Lockheed) replaced the mechanical control system with a hydraulic system. A considerable progress took place in 1953, when Dunlop equipped the Jaguar XK 120 with brake discs. A year later, in 1954, the first ventilated brake disks were implemented to the AlfaRomeo car. But it was not until 1963 that a big truck was equipped with Knorr disk brakes, and in 1969 this technology was applied for the first time in motorcycles (Baker, 1986).

Owing to the stability of operation, the cost of raw-materials and the ease of production, a material commonly used for brake disks is grey cast iron, where graphite occurs in the form of small lamellas that look in the cross-section like threads (graphite lamellar cast irons). Other materials are used in special applications (Rhee et al, 1971).

For example, materials based on carbon composites are used for the production of brake discs intended for racing cars and aircrafts.

In the casting process, moulds are of different complexity, depending on the piece to be manufactured and the required production cycle. However, all moulds are designed for group casting (Fig. 1).

Disc castings are much larger than the finished discs (Fig. 2). This is due to the fact that the uniform material of required technical characteristics, such as hardness, composition and structure only lies at a certain depth below the surface. The casting allowance ranges from 1,5 to $2 \mathrm{~mm}$. This means that $25 \%$ of the casting material is removed during machining (Pompon, 1998).

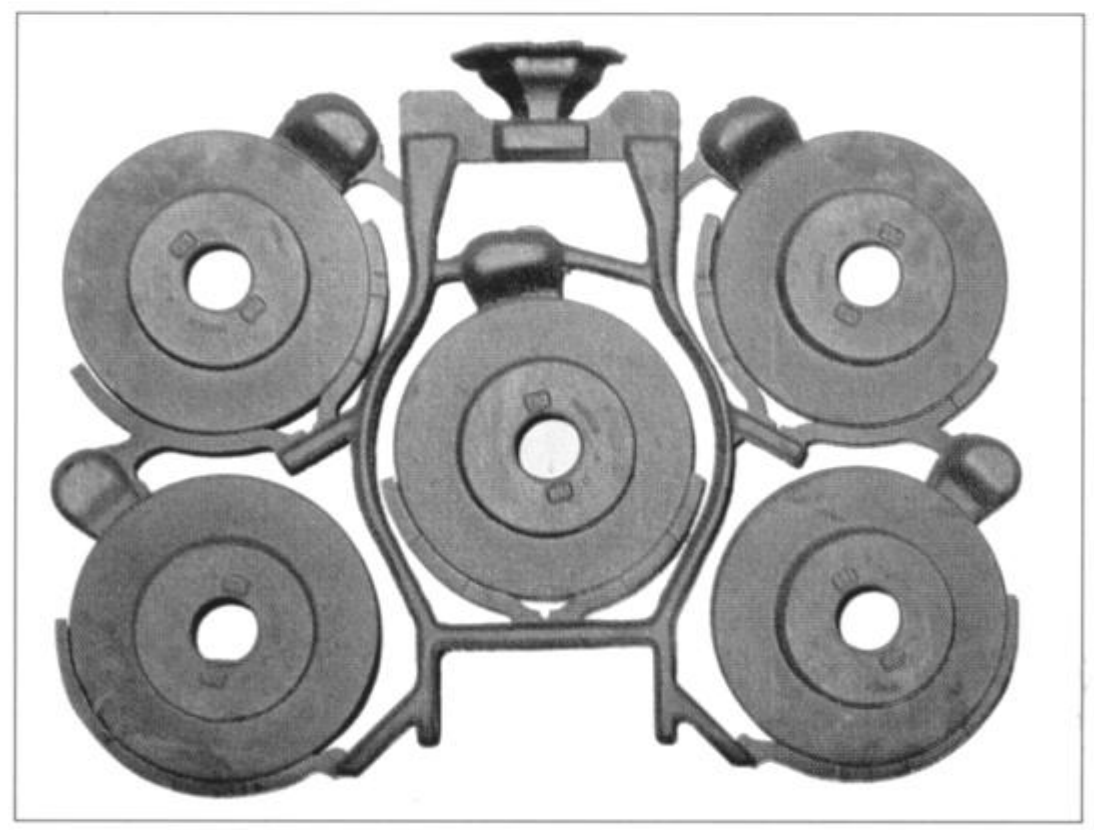

Fig. 1. Cluster casting of brake discs 

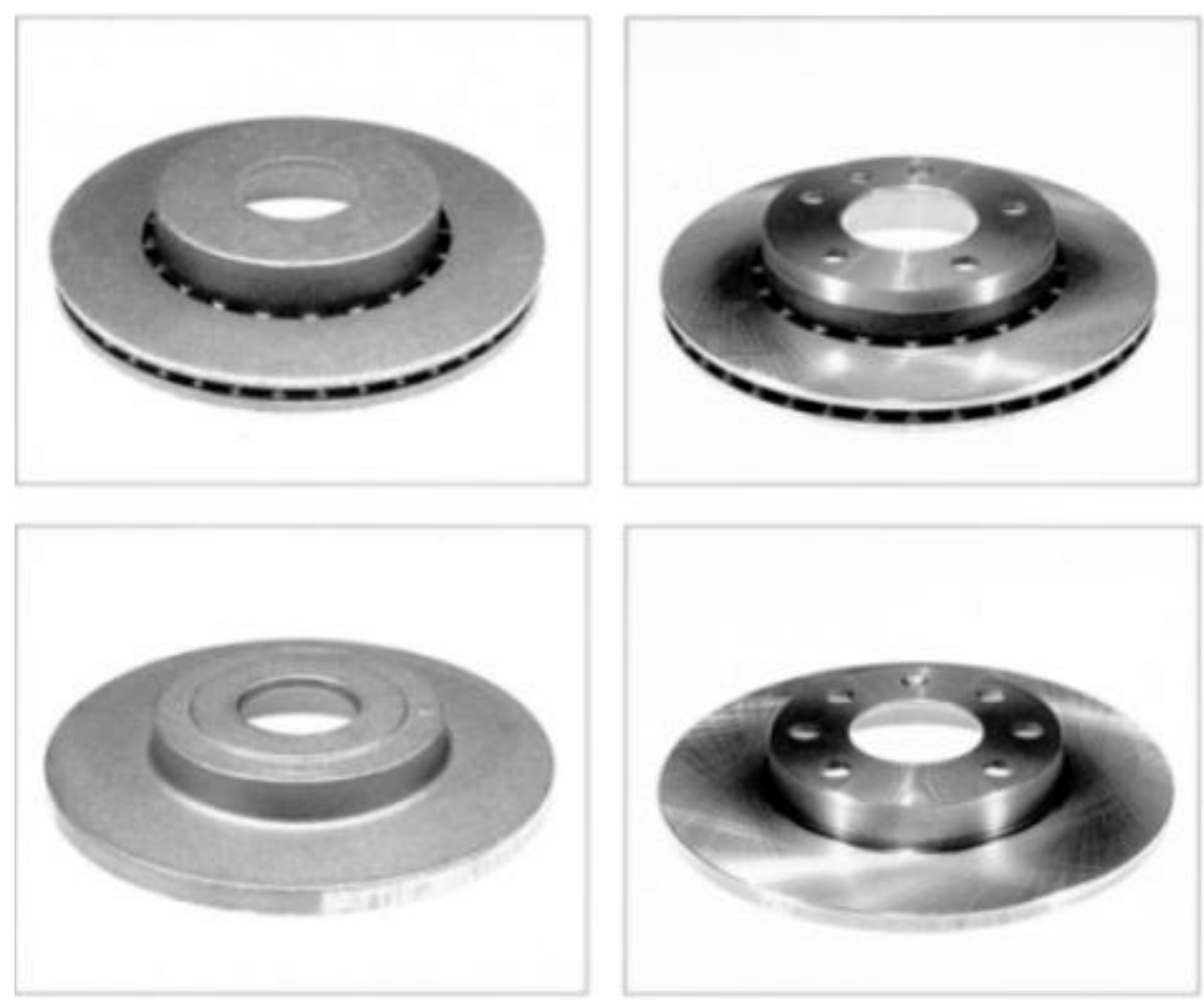

Fig. 2. Casts and final shape of brake discs

High-performance braking systems more and more commonly use ventilated brake discs. Essentially, they are made up of a double disc composed of two plates separated by metal bridges that connect both parts, while forming at the same time passages for the flow of air. Air flows between the two plates and takes away the thermal energy (Harper, 1971). The air circulation depends largely on the shape of internal bridges, which are called "blades" (Fig. 3).
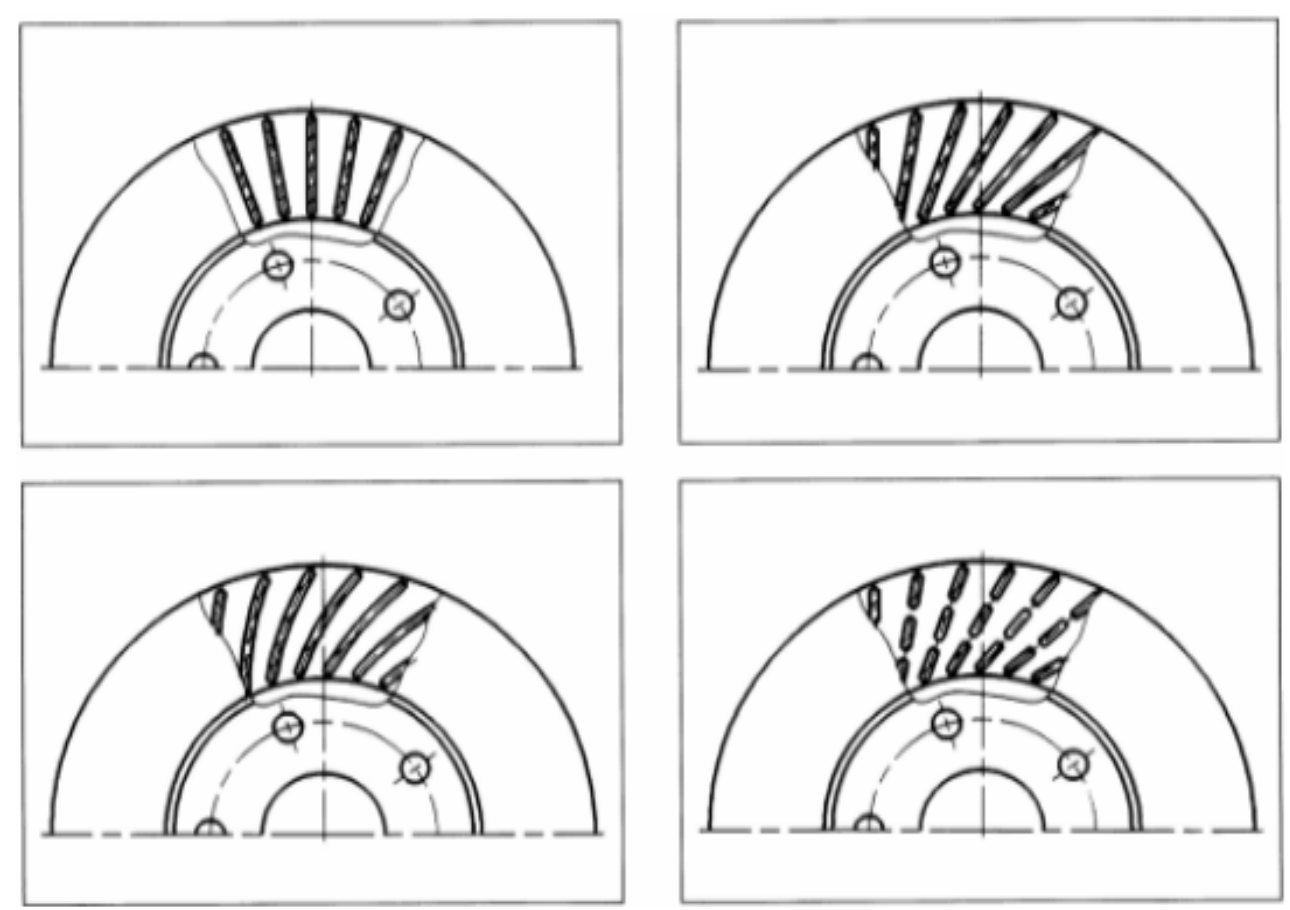

Fig. 3. Different shapes of blades of ventilated brake discs 


\section{Machining of brake discs}

Demand for brake discs, in a global scale, reaches several hundred million units per year, thus their production is a large-lot one.

A technological process of brake discs manufacture in a modern factory producing twelfth thousand discs a day in a three-shift system, with hundred twenty type-sizes a month, intended both for new cars and for servicing purposes is presented.

Basic disc-shaping operations (Fig. 4) are performed semi-automatic machining groups composed of numerically-controlled turning lathes and $\mathrm{CNC}$ drilling machines interconnected with transfer lines.

Turning operations are carried out on PCC job turning lathes manufactured by PITLER. These are two-chamber machines designed for dry machining, with a mobile electro-spindle of a vertical axis of rotation.

\begin{tabular}{|c|c|c|}
\hline Operation & Operation description & Stand \\
\hline 10 & Shot blasting & Shot-blasting machine \\
\hline 20 & $\begin{array}{l}\text { Self-inspection, supervision } \\
\text { inspection }\end{array}$ & Shot-blasting machine \\
\hline 30 & Preliminary turning & CNC turning lathe \\
\hline 40 & Intermediate turning & CNC turning lathe \\
\hline 50 & Final turning & CNC turning lathe \\
\hline 60 & $\begin{array}{l}\text { Self-inspection, supervision } \\
\text { inspection }\end{array}$ & Inspection \& measurement stand \\
\hline 70 & Drilling & CNC drilling machine \\
\hline 80 & $\begin{array}{l}\text { Self-inspection, supervision } \\
\text { inspection }\end{array}$ & Inspection \& measurement stand \\
\hline 90 & Inter-operation preservation & Preservation stand \\
\hline 100 & Balancing & Balancing machine \\
\hline 110 & $\begin{array}{l}\text { Self-inspection, supervision } \\
\text { inspection }\end{array}$ & Inspection \& measurement stand \\
\hline 120 & Inter-operation preservation & Preservation stand \\
\hline 130 & Marking & Marking machine \\
\hline 140 & $\begin{array}{l}\text { Self-inspection, supervision } \\
\text { inspection }\end{array}$ & Inspection \& measurement stand \\
\hline 150 & Automatic inspection & Inspection \& measurement stand \\
\hline 160 & Degreasing, phosphatizing & Degreasing line \\
\hline 170 & $\begin{array}{l}\text { Self-inspection, supervision } \\
\text { inspection }\end{array}$ & Inspection \& measurement stand \\
\hline 180 & Anticorrosive protection & Anticorrosive protection line \\
\hline 190 & $\begin{array}{l}\text { Self-inspection, supervision } \\
\text { inspection }\end{array}$ & Inspection \& measurement stand \\
\hline 200 & Packaging & Packaging stand \\
\hline 210 & Final inspection & Final inspection stand \\
\hline
\end{tabular}

Tab. 1. Specification of basic operations 
$\underline{\underline{E}-\mathrm{E}}$
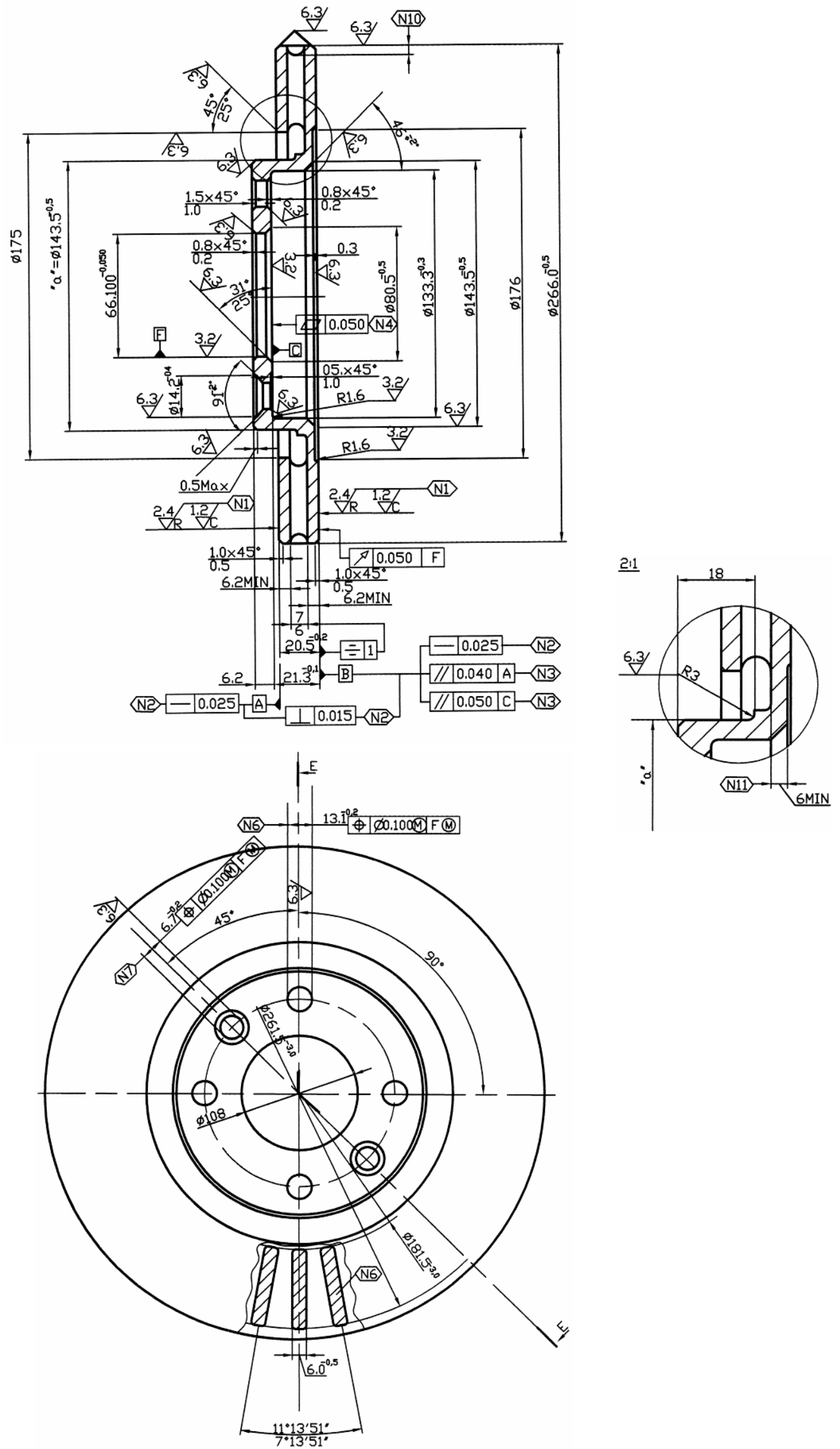

Fig. 4. The ventilated brake disc 


\section{$\underline{\text { Operation } 10}$}

Operation 20

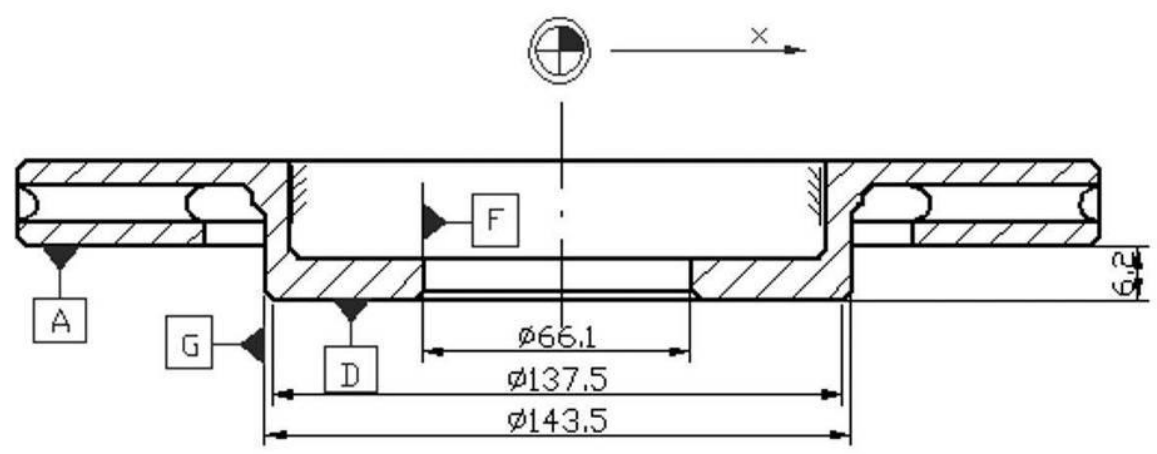

\section{$\underline{\text { Operation } 30}$}

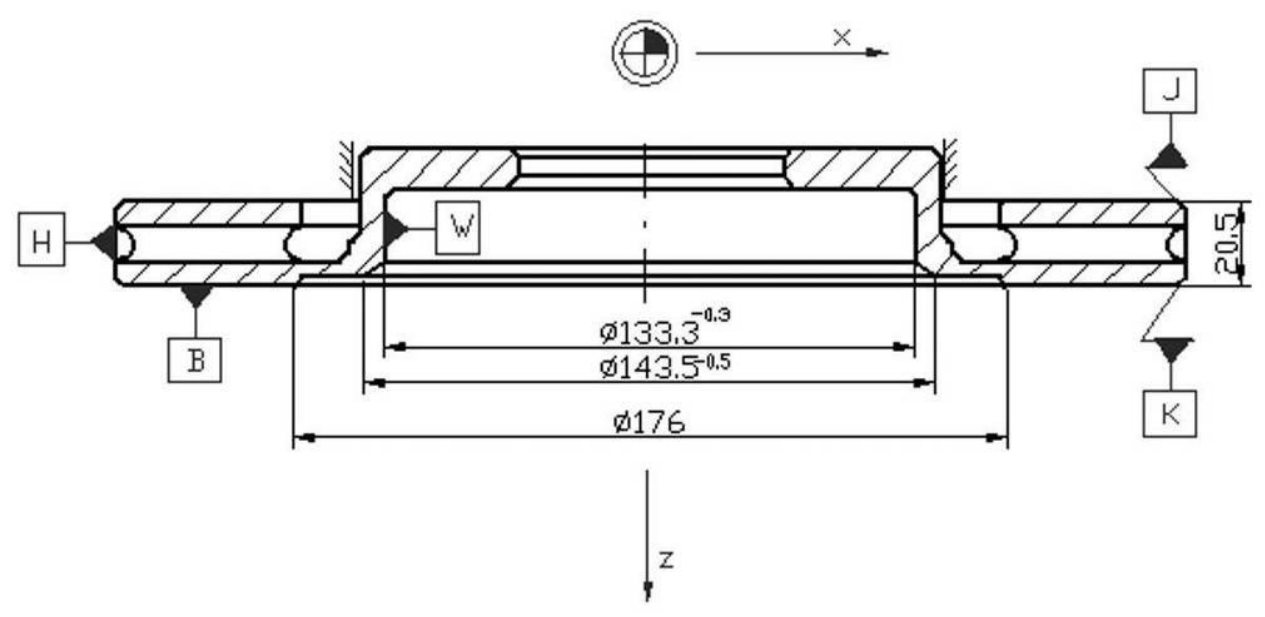

\section{Operation 40}
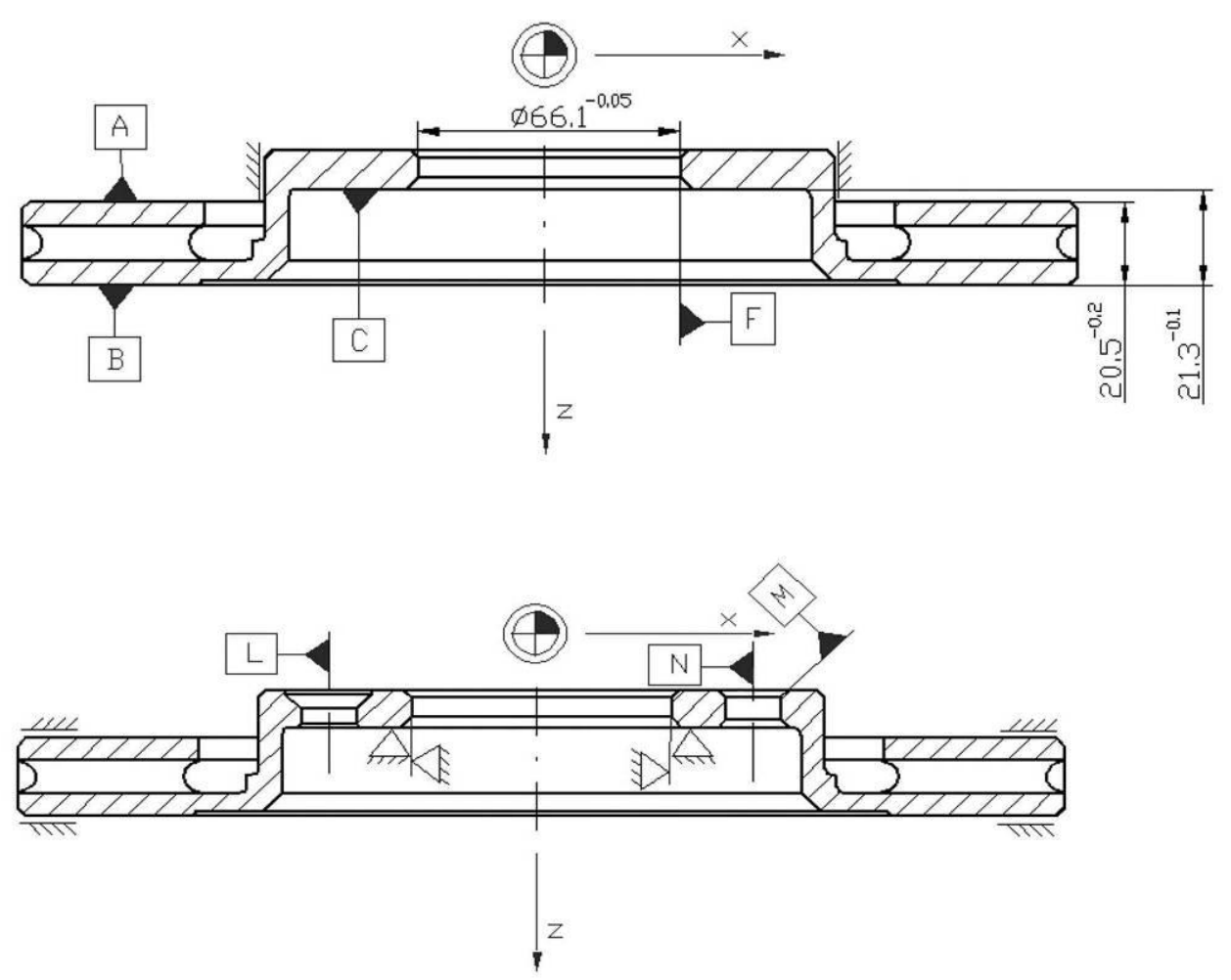

Fig. 5. The ventilated brake disc, the designation of surfaces machined, the system of axes and the characteristic points of four operations 
The power of an AC motor incorporated in the electro-spindle is $72 \mathrm{~kW}$, with a rotational speed range of 11,2 - $5400 \mathrm{~min}^{-1}$ and a maximum spindle torque of $860 \mathrm{Nm}$, whereas the allowable diameter of work piece is $380 \mathrm{~mm}$.

Positioned on a cross slide, the electro-spindle performs longitudinal ( $Z$ axis) movements within a range of $290 \mathrm{~mm}$ at a feed speed of $0-24000 \mathrm{~mm} / \mathrm{min}$, and transverse ( $\mathrm{X}$ axis) movements within a range of $1160 \mathrm{~mm}$ at a feed speed of $0-40000 \mathrm{~mm} / \mathrm{min}$.

The turning lathes are equipped with a turret of a horizontal axis of rotation with eight $\varnothing 50 \mathrm{~mm}$ cylindrical tool sockets. The turret is controlled, as an auxiliary lathe axis, by a SINUMERIK $840 \mathrm{C} / 840 \mathrm{D}$ control system.

Drilling operations in the brake discs technological process are performed on very high-performance CNC drilling machines manufactured by CHIRON.

Both the job turning lathes and the drilling machines are designed to operate with transfer lines and robots.

For all operations machine cutting parameters were optimized and changes in $\mathrm{NC}$ programs for lathes and borers.

The specification of basic operations of the ventilated brake discs technological process is shown in Tab. 1.

\begin{tabular}{|c|c|c|}
\hline Operation & Operation description & Stand \\
\hline 10 & $\begin{array}{l}\text { 1. Coarse machining of surfaces A and D. } \\
\text { 2. Turning of bevel (on surface G) + outer } \\
\text { diameter of bell G. } \\
\text { 3. Finish turning of channel between surface } \\
\text { A - G. } \\
\text { 4. Turning of bevel (at hole F) + coarse turning } \\
\text { of hole F + finishing of face D. }\end{array}$ & $\mathrm{T} 18$ \\
\hline 20 & $\begin{array}{l}\text { 1. Finish turning of outer diameter } \mathrm{H} \text {. } \\
\text { 2. Turning of bevel } \mathrm{J}, \mathrm{K}+\text { coarse turning of } \\
\text { surface } \mathrm{B} \text {. } \\
\text { 3. Finish turning of bell inner diameter W. }\end{array}$ & T19 \\
\hline 30 & $\begin{array}{l}\text { 1. Turning of hole } \mathrm{F}+\text { bevel }(\text { at hole } \mathrm{F})+\text { finish } \\
\text { turning of plane of contact } \mathrm{C} \text {. } \\
\text { 2. Coarse sizing of surface A-B. } \\
\text { 3. Finish sizing of surface A-B. }\end{array}$ & $\mathrm{T} 20$ \\
\hline 40 & $\begin{array}{l}\text { 1. Drilling } \mathrm{L} \text { and } \mathrm{N} \text { on surfaces } \mathrm{D} \text { and } \mathrm{C} \text {. } \\
\text { 2. Beveling } \mathrm{M} \text { and counterboring on surfaces } \\
\mathrm{D} \text { and } \mathrm{C} \text {. }\end{array}$ & $\begin{array}{l}\text { Drilling } \\
\text { machine }\end{array}$ \\
\hline
\end{tabular}

Tab. 2. Specification of four operations and treatments included in the technological process of ventilated brake discs machining 


\section{Modification of the technological process}

A modification to the technological process of ventilated brake disc machining (Fig. 4) was made (Podmagorski, 2003). The main purpose of the modification was to increase the productivity by changing machining parameters for three turning operations and one drilling operation (Fig. 5; Tab. 2) and by using tools with ceramic plates. The machining parameters for sintered carbide tools ranged within $\mathrm{v}_{\mathrm{c}}=200-700 \mathrm{~m} / \mathrm{min}$ and $\mathrm{f}=0,2-0,6 \mathrm{~mm} / \mathrm{rev}$, respectively. Some of those parameters were maximal on account of the capabilities of the control systems. As a result of the modification the time of machining a brake disc was shortened by $20 \%$ on the average (Wolny \& Rygallo, 2006).

The application of ceramic plates increased the productivity by reducing the frequency of their replacement, while meeting the quality requirements for the brake discs (Wolny \& Rygallo, 2008).

\section{Conclusion}

The aim of this paper was achieved. Machine cutting parameters were optimized and changes in NC programs for lathes and borers were implemented. The result of the modification was the time of machining a brake discs shortened, average by $20 \%$. The changes applied to the technological process of brake discs significantly increased the productivity with maintenance of the precision of execution.

\section{References}

Baker, A. K. (1986). Vehicle braking. Pentech Press, Londres: Plymouth Harper, G. A. (1971). A history of brakes and friction materials. IMechE

Podmagorski, M. (2003). Proces technologiczny tarcz hamulcowych wraz $z$ programem na OSN.(Technological process of disc brakes with the program on CNC machine tools). Praca dyplomowa, ITMiAP Politechniki Częstochowskiej, Częstochowa

Pompon, J. P. (1998). Podręcznik tarczy hamulcowej.(Textbook of disc brake) Brembo SpA

Rhee, S. K.; Ducharme, R. T. \& Spurgeon, W. M. (1971). Characterization of cast iron friction surfaces. S.A.E. Lexington Avenue New York Nr 720056

Wolny, R. \& Rygallo, A. (2006). Proces technologiczny obróbki tarcz hamulcowych.(Technological process of disc brakes treatment). International Conference „Production Engineering”, Centrum Zaawansowanych Systemów Produkcyjnych, Instytut Budowy Maszyn i Automatyzacji Politechniki Wrocławskiej, Oficyna Wydawnicza Politechniki Wrocławskiej, ISBN 83-7085989-5, Wrocław

Wolny, R. \& Rygallo, A. (2008). New solution of the technological process of disc brakes machining. Proceedings of the International Conference on Manufacturing Systems, ICMaS, ISSN 1842-3183, Bucharest 